\title{
EKSTRAK LEMAK Gracilaria verrucosa SEBAGAI ANTIBAKTERI Shigella dysentriae DAN Escherichia coli
}

\section{Gracilaria verrucosa Fat Extract as Antibacterial Agent against Shigella $\underline{d y \text { sentriae and Escherichia coli }}$}

\author{
Riong Seulina Panjaitan*, Yulia Verawati Simanjuntak, dan Sumantri \\ IImu Farmasi, Fakultas Farmasi, Universitas 17 Agustus 1945 Jakarta, Jakarta Utara, Indonesia \\ *Korespondensi Penulis: riongpanjaitan@yahoo.co.id \\ Diterima: 15 Oktober 2019; Direvisi: 14 Januari 2020; Disetujui: 26 Maret 2020
}

\begin{abstract}
ABSTRAK
Makroalga merupakan salah satu sumber daya hayati yang melimpah di perairan Indonesia. Genus Gracilaria merupakan salah satu makroalga merah yang diketahui memiliki kandungan metabolit sekunder yang bersifat sebagai antibakteri. Genus ini memiliki ciri thallus agak padat dan keras untuk melekat pada substrat. Penelitian ini bertujuan untuk menguji aktivitas antibakteri lipid/ lemak dari Gracilaria verrucosa. Ekstraksi lipid/lemak dilakukan dengan metode Folch yang dimodifikasi menggunakan teknik Soxhlet dengan perbandingan pelarut metanol : kloroform 1:2 (v/ v). Identifikasi profil asam lemak menggunakan Gas Chromatography-Mass Spectrometry (GC-MS). Uji aktivitas antibakteri berdasarkan metode disc-diffusion dan penentuan konsentrasi hambat minimum (KHM) menggunakan 5 konsentrasi berbeda yaitu, 20\%, 40\%, 60\%, 80\% dan $100 \%(\mathrm{v} / \mathrm{v})$. Bakteri uji yang digunakan adalah Shigella dysentriae dan Escherichia coli. Hasil penelitian menunjukkan kandungan lipid keseluruhan yang diperoleh sebesar $3,45 \%(\mathrm{v} / \mathrm{v})$ dengan komposisi fasa kloroform sebesar 1,15\% (v/v) dan fasa metanol sebesar 2,30\% (v/v). Hasil identifikasi GC-MS menunjukkan bahwa lipid fasa metanol mengandung asam palmitat dan asam oleat. Sedangkan lipid fasa kloroform mengandung asam miristat, asam palmitoleat, asam stearat, asam arakidonat, asam palmitat dan asam oleat. Kedua fasa lipid menunjukkan aktivitas antibakteri terhadap Shigella dysentriae dan Escherichia coli.
\end{abstract}

KATA KUNCI : antibakteri, asam lemak, Escherichia coli, Gracilaria verrucosa, Shigella dysentriae

\begin{abstract}
Macroalga (seaweed) is one of the abundant marine biological resources from Indonesian Waters. Gracilaria is a type of red macroalgae that has secondary metabolites as an antibacterial agent. Gracilaria has thallus that rather dense and hard to attach to the substrate. The objective of this research was to investigate the antibacterial activity of lipids from Gracilaria verrucosa. Lipids were extracted according to Folch method using Soxhlet technique in which the ratio of methanol : chloroform was 1:2 (v/v). Fatty acid profile was identified using Gas Chromatography-Mass Spectrometry (GC$M S$ ). The antibacterial activity was evaluated by disc-diffusion method using five different concentrations to determinate the minimum inhibitory concentration $(20 \%, 40 \%, 60 \%, 80 \%$, and $100 \%(\mathrm{v} / \mathrm{v}))$. Shigella $\underline{d y s e n t r i a e}$ and Escherichia coli were used as test bacteria. The results showed that total lipid amount was $3.45 \%$ with $1.15 \%(\mathrm{~V} / \mathrm{V})$ consisted in chloroform phase and $2.30 \%(\mathrm{~V} / \mathrm{V})$ consisted in methanol phase. GC-MS identification results showed that methanol lipid phase contained palmitic acid and oleic acid, while the chloroform lipid phase had myristic acid, palmitoleic acid, stearic acid, arachidonic acid, palmitic acid and oleic acid. Both of lipid phases showed activities against Shigella dysentriae and Escherichia coli.
\end{abstract}

KEYWORDS: antibacterial, fatty acid, Escherichia coli, Gracilaria verrucosa, Shigella dysentriae

\section{PENDAHULUAN}

Makroalga merupakan salah satu komoditas unggulan dari laut yang dijadikan produk makanan, farmasi dan kosmetik. Salah satu makroalga yang sudah di budidayakan di Indonesia adalah Gracilaria sp., di antaranya di Muara Gembong, Bekasi, Jawa Barat. Pemeliharaan Gracilaria sp. umumnya dilakukan secara polikultur dengan bandeng. Gracilaria banyak dimanfaatkan sebagai bahan baku makanan agar-agar. Gracilariasp. memiliki kandungan senyawa antibakteri yaitu alkaloid, flavonoid dan steroid yang 
terbukti dapat menghambat pertumbuhan bakteri (Siregar, Sabdono, \& Pringgenies, 2012).

Mikroorganisme seperti virus, bakteri dan protozoa adalah penyebab penyakit infeksi saluran cerna. Infeksi yang disebabkan bakteri disebut juga disentri basiler yang disebabkan oleh bakteri Shigella dysentriae, infeksi yang disebabkan oleh protozoa disebut juga disentri amuba. Sedangkan infeksi saluran pencernaan yang dapat menyebabkan diare atau buang air besar berlebih dengan tinja berbentuk cair dan frekuensinya lebih dari tiga kali dalam sehari atau 24 jam disebabkan oleh bakteri Escherichia coli. Riset Kesehatan Dasar (Rikesda) tahun 2017 menunjukkan data prevalensi diare di Indonesia adalah $9 \%$. Terdapat 14 provinsi yang prevalensinya di atas prevalensi nasional, yaitu tertinggi Provinsi Nanggroe Aceh Darussalam sebesar 18,9\% sedangkan Provinsi Daerah Istimewa Yogyakarta terendah 4,2\%. Laporan epidemiologi pada kasus shigellosis menyatakan bahwa terdapat 600.000 dari 140 juta pasien shigellosis meninggal setiap tahun di seluruh dunia. Sedangkan data di Indonesia disentri menyebabkan $29 \%$ kematian pada umur 1 sampai 4 tahun (Bangkele, Nursyamsi, \& Greis, 2015).

Kasus resistensi bakteri Shigella dysentriae dan Escherichia coli terhadap antibiotik telah banyak ditemukan. Hal ini mendorong perlunya dilakukan eksplorasi agen antibakteri baru yang berasal dari bahan alam terutama dari laut untuk mengatasi masalah resistensi bakteri (Bangkele et al., 2015). Lipid Gracilaria sp. diketahui memiliki aktivitas antibakteri terhadap Thiobacillus ferooxidans penyebab korosi pada besi (Afifah, Warganegara, Bundjali, 2016).

Pencarian bahan baku obat dari bahan alam khususnya laut untuk mencegah infeksi dan resistensi bakteri pathogen telah banyak dilakukan seperti penggunaan rumput laut sebagai pengobatan alternatif antibakteri (Riyanto, Widowati, \& Sabdono, 2013). Penelitian bertujuan untuk menguji aktivitas antibakteri berupa lipid dari Gracilaria verrucosa terhadap Shigella dysentriae dan Escherichia coli.

\section{BAHAN DAN METODE}

\section{Bahan}

Makroalga yang digunakan adalah Gracilaria verrucosa yang diperoleh dari tambak daerah Pantai Muara Gembong, Desa Pantai Mekar, Kecamatan Muara Gembong, Kabupaten Bekasi, Jawa Barat. Kecamatan Muara Gembong memiliki posisi astronomis pada $107^{\circ} 10^{\prime \prime}$ BT dan $6^{\circ} 11$ " LS. Sampel segar dari seluruh bagian tanaman kemudian dibersihkan dengan air mengalir lalu dikeringanginkan. Selanjutnya sampel rumput laut yang sudah kering ditimbang sebanyak satu kilogram dimasukkan ke dalam plastik dan disimpan dalam lemari es.

\section{Metode}

\section{Identifikasi rumput laut}

Sampel rumput laut dalam keadaan basah dan segar diidentifikasi di Pusat Penelitian OseanografiLembaga IImu Pengetahuan Indonesia.

\section{Ekstraksi lipid}

Ekstraksi lipid dari rumput laut (G. verrucosa) dilakukan dengan metode Soxhlet menggunakan campuran pelarut metanol : kloroform 1:2 (v/v) yang didasari oleh metode Folch (Folch, Less, \& Stanley, 1957). Hasil ekstrak lipid menghasilkan fasa atas dan fasa bawah. Kedua fase tersebut dipisahkan dengan menggunakan corong pisah. Ekstrak lipid tersebut diuapkan menggunakan rotary evaporator. Lipid yang dihasilkan kemudian dimasukkan ke dalam botol coklat, lalu diberi label kemudian disimpan dalam kulkas pada suhu $4^{\circ} \mathrm{C}$ (Wijaya, Wardayanie, Astuti, \& Arif, 2018).

\section{Identifikasi profil asam lemak dengan Gas Cromatography-Mass Spectrometry(GC-MS)}

Ekstrak lipid/lemak dilarutkan dengan heksan, selanjutnya dimasukkan ke dalam tabung reaksi dan ditambahkan $\mathrm{KOH}$. Campuran dipanaskan pada suhu $60^{\circ} \mathrm{C}$ selama 5 menit, kemudian ditambahkan boron trifluorida $\left(\mathrm{BF}_{3}\right)$ dalam metanol dan dipanaskan pada suhu $60{ }^{\circ} \mathrm{C}$ selama 30 menit. Kemudian larutan ditambah $\mathrm{N}$-hexan dan dipanaskan dengan suhu 60 ${ }^{\circ} \mathrm{C}$ selama 5 menit. Dari hasil ini akan terbentuk asam lemak dari total lipid yang transesterifikasi menjadi metil ester. Sampel ditunggu sampai dingin, selanjutnya ditambahkan $\mathrm{NaCl}$ dan dikocok. Di bagian atas (metil ester lemak yang terbentuk) diambil kemudian diinjeksi sekitar $1 \mu \mathrm{L}$ ke dalam alat GC-MS Agilent series 6890 dengan laju alir 0,35 mL/menit dan split ratio 75:1 (Aryani, Utami, \& Sulistyaningsih, 2017).

\section{Kultur bakteri}

Bakteri Shigella dysentriae dan Escherichia coli diperoleh dari Laboratorium Mikrobiologi, Universitas Indonesia. Bakteri ini dikultur dengan Nutrient Agar (NA) dan diinkubasi selama 24 jam untuk $S$. dysentriae (ATCC 11835) dan 16 jam untuk E. coli pada suhu $37^{\circ} \mathrm{C}$ (BSN, 1992; Cappuccino \& Sherman, 2014). 


\section{Pengujian aktivitas antibakteri ekstrak lipid G. verrucosa}

Pengujian aktivitas antibakteri dilakukan dengan metode disc-diffusion menggunakan kertas cakram. Sebagai kontrol positif digunakan antibiotik tetrasiklin konsentrasi $30 \mu \mathrm{g}$, sedangkan kontrol negatif menggunakan pelarut kloroform dan metanol murni konsentrasi $100 \%$. Cawan petri berisi Nutrien Agar (NA) yang telah dikultur bakteri $S$. dysentriae dan bakteri $E$. coli disebarkan menggunakan batang $L(L$ Rod) dan dibagi menjadi 5 bagian. Kertas cakram yang sebelumnya telah ditetesi dengan ekstrak lipid kemudian dimasukkan ke cawan. Setiap cawan petri diinkubasi pada suhu $37^{\circ} \mathrm{C}$ selama 24 jam untuk bakteri $S$. dysentriae dan 16 jam untuk bakteri $E$. coli. Kemudian diamati dan diukur zona bening atau hambatan yang terbentuk di sekitar kertas cakram dengan jangka sorong. Pengujian dilakukan sebanyak tiga kali (triplo) (Cappuccino \& Sherman, 2014).

\section{Penentuan konsentrasi hambat minimum(KHM)}

Konsentrasi Hambat Minimum (KHM) ditentukan untuk kedua lapisan lipid $G$. verrucosa menggunakan metode disc-diffussion (Uji Kirby Bauer). Pembuatan konsentrasi ekstrak lipid dilakukan dengan cara membuat larutan induk dengan konsentrasi 1.000 .000 ppm (100\%). Dari larutan induk tersebut dibuat berseri sebesar 200.000 ppm (20\%), 400.000 ppm (40\%), 600.000 ppm (60\%), dan 800.000 ppm (80\%). Media Nutrient Agar (NA) yang sudah diinokulasi bakteri diinkubasi selama 24 jam untuk S. dysentriae dan 16 jam untuk E. colipada suhu $37^{\circ} \mathrm{C}$. KHM diukur dengan menghitung zona bening disekitar disc. Pengujian dilakukan sebanyak tiga kali (triplo) (Trisia, Philyria, \& Toemon, 2018).

\section{HASIL DAN PEMBAHASAN}

\section{Hasil Sampling dan Determinasi Makroalga (G. verrucosa)}

Berdasarkan hasil identifikasi, rumput laut yang diperoleh dari tambak daerah Pantai Muara Gembong, Desa Pantai Mekar, Kecamatan Muara Gembong, Kabupaten Bekasi, Jawa Barat adalah species $G$. verrucosa.

Secara visual, makroalga G. verrucosa yang diambil dari tambak berwarna merah kecokelatan memiliki panjang $23 \mathrm{~cm}$ dan membentuk rumput dengan percabangan tidak teratur yang memiliki duri di sekitar bagian cabangnya. Menurut lyer, De Clerck, Bolton, \& Coyne (2014) ciri dari G. verrucosa yaitu talus berbentuk silindris dengan lebar hingga $2 \mathrm{~mm}$, sedangkan pada ujung talus menyempit hingga 0,8 $\mathrm{mm}$ hingga bentuknya meruncing. Warna talus $G$. verrucosa adalah merah tua sampai ungu, umumnya memiliki cystocarps yang tersebar secara tidak teratur pada permukaan talus dengan lebar terbesar adalah $1,4 \mathrm{~mm}$.

\section{Hasil Ekstraksi Lipid Makroalga (G. verrucosa)}

Dari hasil ekstraksi didapat dua lapisan lipid yang disebabkan karena adanya perbedaan berat jenis antar kedua pelarut, metanol memiliki bobot jenis $32,04 \mathrm{~g} / \mathrm{mol}$ sedangkan kloroform memiliki bobot jenis $119,38 \mathrm{~g} / \mathrm{mol}$ (Handayani, Alimin, \& Rustiah, 2014).

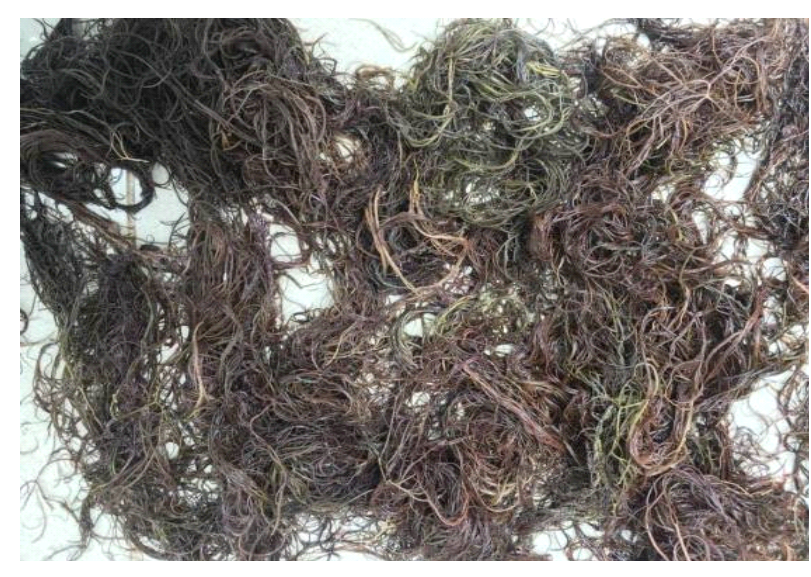

a

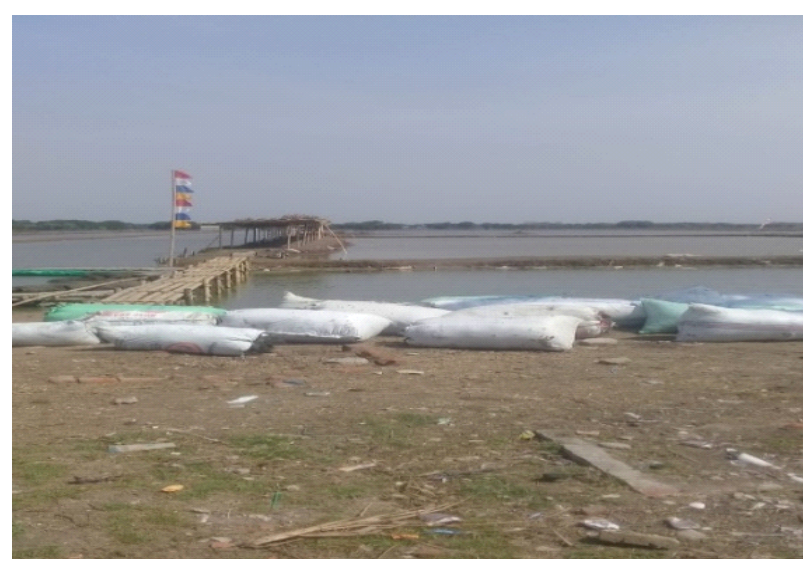

b

Gambar 1. a. G. verrucosa dan b. Tambak Muara Gembong

Figure 1. a. G. verrucosa and b. Muara Gembong Pond 
Dengan demikian kloroform berada di lapisan bawah dan metanol di lapisan atas karena berat jenis dari kloroform lebih besar dari pada metanol.

Total lipid yang diperoleh dari ekstraksi $G$. verrucosa adalah $45 \mathrm{~mL}$ dari $1200 \mathrm{~mL}$ pelaut yang digunakan. Dengan rincian yaitu lipid fasa metanol sebanyak $30 \mathrm{~mL}$ dan fasa kloroform sebanyak $15 \mathrm{~mL}$. Dari kedua fasa tersebut memiliki perbedaan warna, pada lipid fasa metanol berwarna coklat jernih sedangkan lipid fasa kloroform berwarna hijau tua pekat dan keduanya memiliki bau atau aroma yang sama yaitu berbau amis. Adanya perbedaan warna lipid dikarenakan penggunaan pelarut yang berbeda, kloroform merupakan pelarut yang baik untuk mengekstrak lemak/lipid. Lipid sendiri tidak mengandung banyak air sehingga lipid mudah teroksidasi dan mengubah warna lipid menjadi lebih pekat/gelap. Berbeda dengan pelarut metanol yang memiliki sifat polar sehingga lebih banyak mengandung air dari pada lipid sehingga warnanya lebih terang (Handayani et al., 2014)

Berdasarkan Tabel 1 dapat diketahui bahwa kadar lipid total yang didapat sebanyak $3,45 \% \mathrm{v} / \mathrm{v}$ yang terdiri dari, fasa kloroform sebesar $1,15 \% \mathrm{v} / \mathrm{v}$ dan fasa metanol sebesar $2,30 \% \mathrm{v} / \mathrm{v}$. Fasa metanol lebih banyak hampir dua kali lipat dari lipid fasa kloroform. Hasil ini berbeda dengan penelitian sebelumnya pada spesies Gracilaria lainnya seperti Gracilaria arcuate dengan kadar lipid yang di dapat $1,07 \%$ dan Gracilaria salicornia 1,47\% (Mwalugha, Wakibia, Kenji, \&
Mwasaru, 2015) dan G. salicornia kadar lipid yang didapat 2,00\% (Tabarsa, Rezaei, Ramezanpour, \& Waaland, 2012). Perbedaan kadar lipid yang didapat dipengaruhi beberapa faktor di antaranya, jenis makroalga, lingkungan pertumbuhan makroalga terutama suhu serta faktor ekstraksi (waktu, pelarut, luas permukaan, perbandingan bahan dan pelarut (Sanchez-Machado, Lopez-Cervantes, LopezHernandez, \& Paseiro-Losada, 2004).

Fleurence (2016) dan Ate, da Costa dan Elingsetyo (2017), mengemukakan dalam penelitiannya bahwa kadar lipid semua jenis rumput laut sangat rendah yakni bekisar antara $0,9-4,0 \% \mathrm{v} / \mathrm{v}$ berat kering. Kadar lipid dari makroalga $G$. verrucosa masih dalam rentang kadar lipid yang ditemukan dari berbagai jenis rumput laut yaitu $1,15 \% \mathrm{v} / \mathrm{v}$ untuk fasa kloroform dan 2,30\% $\mathrm{v} / \mathrm{v}$ fasa metanol.

\section{Hasil Karakterisasi Lipid G. verrucosa dengan GC-MS}

Tabel 2 dan 3 menunjukkan hasil GC-MS, pada fasa metanol terdapat 2 jenis asam lemak yaitu asam lemak jenuh asam hexadecanoic $0,07 \% \mathrm{v} / \mathrm{v}$ dan asam lemak tidak jenuh asam 9-octadecenoic 0,05\% v/v. Sedangkan untuk fasa kloroform terdapat 7 jenis asam lemak yang terdiri dari asam lemak jenuh yaitu asam miristat $0,07 \% \mathrm{v} / \mathrm{v}$; asam 9 -hexadecanoic 3,2\% v/v; asam 9 -octadecanoic $0,11 \% \mathrm{v} / \mathrm{v}$, asam lemak tak jenuh yaitu asam octadecenoic $0,45 \% \mathrm{v} / \mathrm{v}$ dan asam hexadecenoic $0,05 \% \mathrm{v} / \mathrm{v}$, asam lemak essensial yaitu

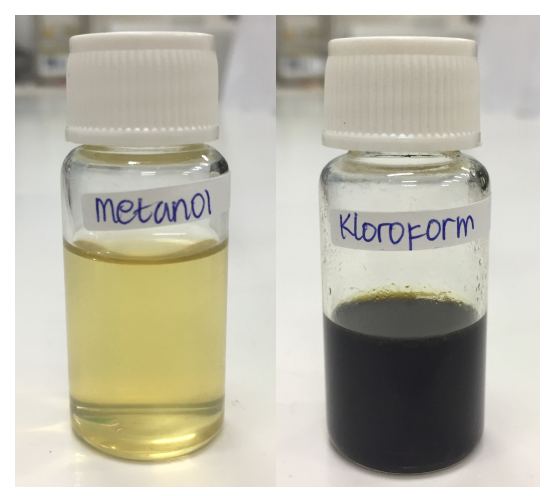

Gambar 2. Lipid G. verrucosa fasa metanol dan kloroform Figure 2. Lipids of $\underline{G}$ verrucosa methanol and chloroform phase

Tabel 1. Kadar lipid G. verrucosa

Table 1. Lipid content of $\underline{G}$ verrucosa

\begin{tabular}{lc}
\hline \multicolumn{1}{c}{ Pelarut/Solvent } & $\begin{array}{c}\text { Kadar Lipid/Lipid Content } \\
(\% \mathrm{v} / \mathrm{v})\end{array}$ \\
\hline Kloroform/Chloroform & $1.15 \% \mathrm{v} / \mathrm{v}$ \\
Metanol/Methanol & $2.30 \% \mathrm{v} / \mathrm{v}$ \\
\hline
\end{tabular}


asam $5,8,11,14$-eicosatetraenoic $0,05 \% \mathrm{v} / \mathrm{v}$ dan asam 7,10,13-eicosatrienoic $0,05 \% \mathrm{v} / \mathrm{v}$.

Kandungan lipid total dari makroalga Gracilaria sp. yang dikoleksi dari Lesina Lagoon (Southern Adriatic Sea, Lesina, Italy), paling tinggi sebanyak $1,98 \%$ v/v pada bulan Juli 2011 dan terendah sebanyak $1,12 \% \mathrm{v} / \mathrm{v}$ pada bulan Januari 2012. Asam arakidonat dan asam palmitat mendominasi kelimpahan asam lemak pada Gracilaria gracilis tersebut (Francavilla, Franchi, Monteleone, \& Caroppo, 2013).

Asam lemak jenuh mewakili sebagian besar asam lemak yang ditemukan dalam rumput laut yang sedang diteliti, fakta tersebut juga dijelaskan oleh Bhaskar et al. (2004) yang melaporkan bahwa kandungan asam lemak jenuh yang tinggi mungkin karena pengaruh suhu air, air dari lokasi pemanenan ganggang memiliki suhu sedang.

Menurut Handayani, Sutarno, dan Setyawan (2004), pada rumput laut Sargassum crassifolium ditemukan asam lemak jenuh yang dominan adalah asam palmitat
(16:0) dan asam lemak tidak jenuh yang dominan adalah asam linoleat (18:2). Hal ini sesuai dengan pernyataan Lehninger (1997) yang menyebutkan bahwa hampir semua asam lemak di alam mempunyai jumlah atom $C$ yang genap, asam lemak dengan atom C 16 dan 18 adalah yang paling dominan, kadar asam lemak tidak jenuh hampir dua kali lipat asam lemak jenuh.

Dalam penelitian sebelumnya, persentase total asam lemak jenuh rumput laut $G$. gracilis adalah $0,12 \%$ dan asam lemak tak jenuh 0,07\%. Untuk masing-masing asam lemak, asam palmitat dengan atom $\mathrm{C} 16$ adalah asam lemak jenuh utama sementara asam laurat dengan atom $\mathrm{C} 12$ dan asam miristat atom C 14 memiliki nilai yang sama. Sedangkan asam lemak tak jenuh, termasuk asam oleat (C 18:1) dan asam linoleat (C 19: 2) masing-masing adalah 0,05\% dan $0,02 \%$ (Rasyid, Ardiansyah, \& Pangestuti, 2019). Francavilla et al. (2013) juga menyatakan bahwa asam palmitat dan asam arakidonat yang paling dominan pada rumput laut $G$. gracilis.

Tabel 2. Komposisi asam lemak G. verrucosa fasa kloroform

Table 2. Fatty acid composition of chloroform phase of $\underline{G}$ verrucosa

\begin{tabular}{|c|c|c|c|c|}
\hline $\begin{array}{c}\text { No. } \\
\text { Puncak/ } \\
\text { Peak }\end{array}$ & $\begin{array}{l}\text { Indeks Retensi/ } \\
\text { Index Retention }\end{array}$ & $\begin{array}{l}\text { Nama IUPAC/ } \\
\text { IUPAC Name }\end{array}$ & $\begin{array}{l}\text { Rumus Molekul/ } \\
\text { Molecular Formula }\end{array}$ & $\begin{array}{r}\text { Kandungan/ } \\
\text { Content (\%) }\end{array}$ \\
\hline 1 & 16.656 & Asam Miristat/Tetradecanoic Acid & C 14:0 & 0.07 \\
\hline 2 & 18.871 & $\begin{array}{l}\text { Asam Palmitoleat/9-Hexadecenoic } \\
\text { Acid }\end{array}$ & C $16: 1$ & 0.05 \\
\hline 3 & 19.064 & $\begin{array}{l}\text { Asam Palmitat/Hexadecanoic } \\
\text { Acid }\end{array}$ & C 16:0 & 3.02 \\
\hline 4 & 20.867 & Asam Oleat/9-Octadecenoic Acid & C $18: 1$ & 0.45 \\
\hline 5 & 21.039 & Asam Stearat/Octadecanoic Acid & C 18:0 & 0.11 \\
\hline 6 & 22.425 & $\begin{array}{l}\text { Asam Arakidonat } / 5,8,11,14- \\
\text { Eicosatetraenoic Acid }\end{array}$ & C 20:4 & 0.26 \\
\hline 7 & 22.574 & $\begin{array}{l}\text { Asam homolinolenic/7,10,13- } \\
\text { Eicosatrienoic Acid }\end{array}$ & C 20:3 & 0.05 \\
\hline
\end{tabular}

Tabel 3. Komposisi asam lemak G. verrucosa fasa metanol Table 3. Fatty acid composition of methanol phase of $\underline{G}$ verrucosa

\begin{tabular}{ccccc}
\hline $\begin{array}{c}\text { No. Puncak/ Indeks Retensi/ } \\
\text { Peak }\end{array}$ & $\begin{array}{c}\text { Retention Index } \\
\text { Rama IUPAC/ } \\
\text { IUPAC Name }\end{array}$ & $\begin{array}{c}\text { Rumus Molekul/ } \\
\text { Molecular Formula }\end{array}$ & $\begin{array}{c}\text { Kandungan/ } \\
\text { Content (\%) }\end{array}$ \\
\hline 1 & 19.087 & $\begin{array}{l}\text { Asam Palmitat/Hexadecanoic } \\
\text { Acid }\end{array}$ & C $16: 0$ & 0.07 \\
2 & 20.889 & $\begin{array}{l}\text { Asam Oleat/9-Octadecenoic } \\
\text { Acid }\end{array}$ & C $18: 1$ & 0.05 \\
\hline
\end{tabular}




\section{Aktivitas Antibakteri Ekstrak Lipid G verrucosa terhadap S. dysentriae dan E. coli}

Kedua lapisan lipid G. verrucosa menunjukkan adanya aktivitas antibakteri terhadap bakteri $S$. dysentriae dan E. coli. Tabel 4 menunjukkan bahwa fasa kloroform ekstrak lipid memiliki aktivitas lebih besar, khususnya yang ditunjukan pada konsentrasi 1.000 .000 ppm (100\%), fasa metanol pada konsentrasi yang sama hanya memberikan diameter zona bening sebesar 2,74 mm. Konsentrasi hambat minimum pada kedua fasa lipid yaitu 600.000 ppm (60\%) masih dapat menghambat bakteri $S$. dysentriae.

Berbeda dari hasil aktivitas terhadap bakteri $S$. dysentriae, aktivitas antibakteri terhadap E. coli (Tabel 5) menunjukkan bahwa ekstrak lipid yang memiliki aktivitas lebih besar adalah fase metanol pada konsentrasi $1.000 .000 \mathrm{ppm}(100 \%)$, di mana memberikan diameter zona yang jelas sebesar 3,43 $\mathrm{mm}$. Zona penghambatan yang dihasilkan oleh lipid fase kloroform pada konsentrasi 1.000 .000 ppm $(100 \%)$ adalah $3,21 \mathrm{~mm}$. Konsentrasi hambat minimum kedua fasa lipid yaitu pada konsentrasi 600.000 ppm (60\%).

Pada 400.000 ppm (40\%) dan 200.000 ppm (20\%) tidak dianggap menghambat bakteri sebab kontrol negatif menghasilkan diameter zona hambat lebih besar dibandingkan kedua konsetrasi tersebut. Hal tersebut didukung oleh pernyataan dari Pelczar dan Chan (1988) yang menyatakan bahwa salah satu yang mempengaruhi aktivitas senyawa antibakteri, yaitu konsentrasi bahan antibakteri. Daya hambat yang dihasilkan oleh bahan antibakteri akan semakin tinggi jika konsentrasinya juga tinggi (Al Amrie, Ivan, Anam, \& Ramadhanil, 2014). Untuk antibiotik tetrasiklin diperoleh zona bening sekitar $16,13 \mathrm{~mm}$ pada bakteri S. dysentriae dan $22,88 \mathrm{~mm}$ pada bakteri E. coli.

Kaimudin, Siti dan Amahoru (2018) melaporkan bahwa, ekstrak etil asetat Gracilaria sp. mempunyai daya hambat terhadap bakteri ditandai dengan terbentuknya zona bening di area sekitar kertas cakram. Nilai zona hambat yang dihasilkan untuk menghambat bakteri Salmonella enterica Serovar Enteritidis sebesar $4,73 \mathrm{~mm}$ dan sebesar $7,91 \mathrm{~mm}$ pada bakteri Pseudomonas aeruginosa. Besaran nilai zona hambat yang diperoleh, menunjukkan bahwa Gracilaria sp. memiliki aktivitas bakteriosidal.

Melki, Putri, dan Kurniati (2011) melaporkan di dalam penelitiannya bahwa ekstrak metanol Gracilaria sp. memiliki daya hambat bakteri E. coli dan Staphylococcus aureus dengan membentuk daya hambat pada bakteri $E$. coli sebesar 14,33 $\pm 3,22 \mathrm{~mm}$ dan $S$. aureus sebesar $12,67 \pm 2,08 \mathrm{~mm}$ dengan nilai MIC 0,05\%. Sedangkan Siregar (2012) di dalam penelitiannya mendapatkan adanya aktivitas antibakteri ekstrak n-heksan rumput laut terhadap bakteri $P$. aeruginosa, Staphylococcus epidermis dan Micrococcus luteus yang menyebabkan penyakit pada kulit.

Ekstrak lipid dari rumput laut Ulva fasciata dan Dilophys fasciola memiliki aktivitas sedang untuk menghambat jamur Aspergillus niger dan Candida albicans. Sedangkan pada lipid dari makroalga $D$.

Tabel 4. Aktivitas antibakteri lipid G. verrucosa terhadap S. dysentriae

Table 4. Antibacterial activity of $\underline{G}$. verrucosa lipid against $\underline{\text { S. }} \underline{\text { dysentriae }}$

\begin{tabular}{|c|c|c|}
\hline $\begin{array}{l}\text { Kadar Ekstrak Lipid/ } \\
\text { Lipid Extract Levels }\end{array}$ & $\begin{array}{c}\text { Rata-rata Zona Hambat } \\
\text { (mm) pada Ekstrak Lipid } \\
\text { Fasa Kloroform/ } \\
\text { Inhibition Zone A verage } \\
(\mathrm{mm}) \text { in the Chloroform } \\
\text { Phase of Lipid Extract }\end{array}$ & $\begin{array}{c}\text { Rata-rata Zona Hambat } \\
(\mathrm{mm}) \text { pada Ekstrak Lipid } \\
\text { Fasa Metanol/ } \\
\text { Inhibition Zone Average } \\
(\mathrm{mm}) \text { in Methanol Phase of } \\
\text { Lipid Extract }\end{array}$ \\
\hline $1,000,000$ ppm (100\%) & 2.92 & 2.74 \\
\hline 800,000 ppm (80\%) & 1.41 & 1.79 \\
\hline 600,000 ppm $(60 \%)$ & 0.59 & 1.36 \\
\hline 400,000 ppm (40\%) & 0.13 & 0.33 \\
\hline 200,000 ppm (20\%) & 0.02 & 0.05 \\
\hline Kontrol Negatif/Negative Control & 0.54 & 0.35 \\
\hline Kontrol Positif/Positive Control & \multicolumn{2}{|c|}{16.13} \\
\hline
\end{tabular}


Tabel 5. Aktivitas antibakteri lipid G. verrucosa terhadap E. coli

Table 5. Antibacterial activity of $\underline{G}$. verrucosa lipid against $\underline{E}$. coli

\begin{tabular}{ccc}
\hline Kadar Ekstrak Lipid/ & $\begin{array}{c}\text { Rata-rata Zona Hambat } \\
\text { (mm) pada Ekstrak Lipid }\end{array}$ & $\begin{array}{c}\text { Rata-rata Zona Hambat } \\
\text { (mm) pada Ekstrak Lipid }\end{array}$ \\
& $\begin{array}{c}\text { Fasa Kloroform/Inhibition } \\
\text { Zone Average }(\mathbf{m m}) \text { in the } \\
\text { Chloroform Phase of Lipid } \\
\text { Extract }\end{array}$ & $\begin{array}{c}\text { Fasa Metanol/Inhibition } \\
\text { Zone Average }(\mathbf{m m}) \text { in } \\
\text { Methanol Phase of Lipid } \\
\text { Extract }\end{array}$ \\
\hline $1.000 .000 \mathrm{ppm}(100 \%)$ & 3.21 & 3.42 \\
$800.000 \mathrm{ppm}(80 \%)$ & 1.56 & 1.53 \\
$600.000 \mathrm{ppm}(60 \%)$ & 0.91 & 0.49 \\
$400.000 \mathrm{ppm}(40 \%)$ & 0.25 & 0.05 \\
$200.000 \mathrm{ppm}(20 \%)$ & 0.1 & 0.01 \\
Kontrol Negatif/Negative Control & 0.37 & 0.39 \\
Kontrol Positif/Positive Control & & 22.88 \\
\hline
\end{tabular}

fasciola memiliki aktivitas penghambatan maksimal terhadap bakteri E. coli. Lipid ekstrak makroalga $D$. fasciola tidak menghambat bakteri Bacillus subtilis (El Baz, El-Baroty, Ibrahim, \& Abd El Baky, 2014).

Davis dan Stout (1971) menyatakan skala kekuatan antibakteri untuk menghambat pertumbuhan bakteri dikategorikan sesuai dengan ukuran dari zona bening yang terbentuk yaitu, apabila diameter $>20 \mathrm{~mm}$ dinyatakan sangat kuat, diameter $10-20 \mathrm{~mm}$ dinyatakan kuat, dan untuk diameter 5-10 mm dinyatakan medium (cukup) sedangkan apabila diameter $<5 \mathrm{~mm}$ maka dinyatakan lemah.

Dengan demikian lipid dari G. verrucosa baik lipid fasa kloroform dan lipid fasa metanol memiliki aktivitas antibakteri dalam menghambat pertumbuhan bakteri $S$. dysentriae dan E. coli walaupun aktivitasnya tergolong lemah.

Total volume lipid (gabungan volume lipid dari dua fasa) yang diperoleh dari ekstraksi $G$ verrucosa adalah $45 \mathrm{~mL}$ dari 1300 gram makroalga dan kadar lipid total yang diperoleh pada penelitian ini sebanyak 3,45\% v/ v. Lipid G. verrucosa pada fasa metanol mengandung dua jenis asam lemak sedangkan pada fasa kloroform mengandung tujuh jenis asam lemak.

Dari hasil uji aktivitas antibakteri seperti yang telah diuraikan sebelumnya bahwa kedua fasa lipid $G$. verrucosa pada konsentrasi 1.000 .000 ppm (100\%) menunjukkan aktivitas signifikan dibanding konsentrasi lainnya. Kosentrasi Hambat Minimum (KHM) yang didapat dari kedua fasa lipid $G$. verrucosa yaitu pada konsentrasi 600.000 ppm (60\%) masih dapat menghambat bakteri $S$. dysentriae dan E. coli. Dengan demikian asam lemak dari G. verrucosa memiliki kekuatan lemah untuk menghambat pertumbuhan dari kedua bakteri.

\section{KESIMPULAN}

Kesimpulan dari penelitian ini adalah lipid $G$. verrucosa memiliki daya aktivitas antibakteri terhadap pertumbuhan bakteri $S$. dysentriae dan $E$. colidengan Konsentrasi Hambat Minimum (KHM) adalah 600.000 ppm (60\%) dan ekstrak lipid G. verrucosa fasa metanol ataupun kloroform memiliki kekuatan lemah untuk menghambat pertumbuhan kedua bakteri tersebut.

Saran yang dapat diberikan yaitu perlu adanya penelitian lebih lanjut seperti uji toksisitas dan juga uji klinis untuk lipid G. verrucosa agar dapat dimanfaatkan lebih lanjut.

\section{UCAPAN TERIMA KASIH}

Penulis mengucapkan terima kasih kasih kepada Pusat Penelitian Oseanografi LIPI Ancol, Jakarta Utara atas determinasi spesies rumput laut (makroalga).

\section{DAFTAR PUSTAKA}

Afifah, I., Warganegara, F. M., Bundjali, B. (2016). Uji Kualitatif Dan Kuantitatif Ekstrak Sargassum sp. dan Gracilaria sp. Sebagai Inhibitor Bio-Korosi Pada Baja Karbon. Jurnal Kimia dan Pendidikan, 1(2). http:// dx.doi.org/10.30870/educhemia.v1i2.765

Al Amrie, A. G., Ivan., Anam, S., \& Ramadhanil. (2014). Uji Efektifitas Ekstrak Daun dan Akar Harrisonia perforata Merr. terhadap Pertumbuhan Bakteri Vibrio cholerae. Online Jurnal of Natural Science. 3(3), 331-340.

Aryani, T., Utami, F. S., \& Sulistyaningsih, S. (2017). Identifikasi Asam Lemak Omega Pada Asi Eksklusif Menggunakan Kromatografi GC-MS. Journal of Health Studies, 1(1), 1-7. https://doi.org/10.31101/jhes.180

Ate, J. N. B., da Costa , J. F., \& Elingsetyo S. T. P., (2017).Analisis Kandungan Nutrisi Gracilaria edule 
(S.G. Gmelin) P.C. Silva dan Gracilaria coronopifolia J. Agardh untuk Pengembangan Perekonomian Masyarakat Pesisir. Jurnal IImu Kesehatan. 5(2). https:/ /doi.org/10.30650/jik.v5i2.57.

Badan Standar Nasional (BSN). (1992). Metode Pengujian Susu Segar. Jakarta : Badan Standar Nasional.

Bangkele, E. Y., Nursyamsi, \& Greis, S. (2015). Efek Anti Bakteri Dari Ekstrak Lengkuas Putih (Alpinia galangal [L] Swartz) terhadap Shigella dysenteriae. Jurnal Kesehatan Tadulako, 1(2), 52-60.

Bhaskar, N., Kinami, T., Miyashita, K., Park, S. B., Endo, Y., \& Fujimoto, K. (2004). Occurence of conjugated polyenoic fatty acids in seaweeds from the Indian Ocean. Zeitschrift fur Naturforschung 59, 310-314. http://10.1515/znc-2004-5-602

Cappuccino, J. G., \& Sherman, N. (2014). Manual Laboratorium Mikrobiologi Edisi 8. Jakarta : EGC

Davis, W. W., \& Stout, T. R. (1971). Disk plate method of microbiological antibiotic assay. American Society for Microbiology, 4(22).

El Baz, F. K., El-Baroty, G. S., Ibrahim, A. E., \& Abd El Baky, H. H. (2014). Cytotoxicity, antioxidants and antimicrobial activities of lipids extracted from some marine algae. Journal of Aquaculture Research and Development, 5(7). https://doi.org/10.4172/21559546.1000284

Fleurence, J. (2016). Seaweed as Food, In : Seaweed in Health and Disease Prevention (ed) Fleurence, J. and Levine, I., Elsevier Inc. Oxfrod, UK 156.

Folch, J., Lees, M., \& Sloane Stanley, G. H. (1957). A simple method for the isolation and purification of total lipides from animal tissues. The Journal of Biological Chemistry, 226(1), 497-509. https://doi.org/10.3989/ scimar.2005.69n187

Francavilla, M., Massimo, F., Massimo Monteleone., \& Carmela, C. (2013). The Red Seaweed Gracilaria gracilis as a Multi Products Source. Mar. Drugs 1, 3754-3776. http://10.3390/md11103754.

Handayani, A., Alimin., \& Rustiah, W. O. (2014). Pengaruh Penyimpanan pada Suhu Rendah (Freezer $-3{ }^{\circ} \mathrm{C}$ ) Terhadap Kandungan Air dan Kandungan Lemak Pada Ikan Lemuru (Sardinella longiceps). Journal Kimia UIN Alauddin, 2(1).

Handayani, T., Sutarno., \& Setyawan, A. D. (2004). Nutritional Composition Analysis of Seaweed Sargassum crassifolium J. Agardh. Biofarmasi 2(2), 45-52. http://10.13057/biofar/f020201.

lyer, R., De Clerck, O., Bolton, J. J., \& Coyne, V. E. (2004). Morphological and taxonomic studies of Gracilaria and Gracilariopsis species (Gracilariales, Rhodophyta) from South Africa. South African Journal of Botany, 70(4), 521-539. https://doi.org/10.1016/ S0254-6299(15)30192-7
Kaimudin, M., \& Amahoru S. R. (2018). Pemanfaatan Ekstrak Gracilaria sp. sebagai Penghambat Bakteri Salmonella Enteric SV Enteritdis dan Pseudomonas Aeroginosa. Majalah BIAM, 14(01), 14-21.

Lehninger, A. L. (1997). Dasar-Dasar Biokimia. Jilid I (Edisi Revisi). Erlangga: Jakarta

Melki., Putri, W, A, E., \& Kurniati. (2011). Uji antibakteri ekstrak Gracilaria sp (Rumput Laut) terhadap bakteri Escherichia coli dan Staphylococcus aureus. Seminar dan Rapat Tahunan Bidang IImu MIPA.

Mwalugha, H. M., Wakibia, J. G., Kenji, G. M., \& Mwasaru, M. A. (2015). Chemical composition of common seaweeds from the Kenya Coast. J. of Food Res 4, 28-36.

Pelczar, M. J., \& Chan, E. C. S. (1988). Dasar-Dasar Mikrobiologi. Jakarta: Universitas Indonesia Press

Rasyid, A., Ardiansyah, A., \& Pangestuti, R. (2019). Nutrient Composition of Dried Seaweed Gracilaria gracilis. IImu Kelautan: Indonesian Journal of Marine Sciences,24(1),1.https://doi.org/10.14710/ik.ijms.24.1.1-6

Riyanto, E, I., Widowati, I., \& Sabdono, A. (2013). Skrining Aktivitas Antibakteri pada Ekstrak Sargassum polycystum terhadap Bakteri Vibrio harveyi dan Micrococcus luteus di Pulau Panjang Jepara. Journal of Marine Research. 115-121.

Siregar A. F., Sabdono, A., \& Pringgenies, D. (2012). Potensi Antibakteri Ekstrak Rumput Laut Terhadap Bakteri Penyakit Kulit Pseudomonas aeruginosa, Staphylococcus epidermidis, dan Micrococcusluteus. Journal Of Marine Research. 1(2), 152-160. https:// doi.org/10.14710/jmr.v1i2.2032.

Tabarsa, M., Rezaei, M., Ramezanpour, Z., \& Waaland, J. R. (2012). Chemical compositions of the marine algae Gracilaria salicornia (Rhodophyta) and Ulva lactuca (Chlorophyta) as a potential food source. Journal of the Science of Food and Agriculture, 92(12), 2500-2506. https://doi.org/10.1002/jsfa.5659

Trisia, A., Philyria, R., \& Toemon, A. N. (2018). Uji Aktivitas Antibakteri Ekstrak Etanol Daun Kalanduyung (Guazuma ulmifolia Lam.) Terhadap Pertumbuhan Staphylococcus aureus Dengan Metode Difusi Cakram (Kirby-Bauer). Anterior Jurnal, 17(2), 136143. https://doi.org/10.33084/anterior.v17i2.12

Sanchez-Machado, D. I., Lopez-Cervantes, J., LopezHern'andez, J., \& Paseiro-Losada P. (2004). Fatty acids, total lipid, protein and ash contents of processed edible seaweeds, Food Chem. 85(3), 439-444. http://10.1016/j.foodchem.2003.08.001

Wijaya, H., Wardayanie, N. I. A., Astuti, R. M., \& Arif, R. (2018). Isolasi Senyawa $\alpha$-Karoten dari Minyak Kelapa Sawit Mentah (Elaeis Guineensis Jacq.) dengan Metode Kromatografi Kolom Terbuka. Warta Industri Hasil Pertanian, 35(2), 74. https://doi.org/10.32765/ wartaihp.v35i2.3977 